Article

\title{
Salt Stress Effects on Avocado (Persea americana Mill.) Plants with and without Seaweed Extract (Ascophyllum nodosum) Application
}

\author{
Claudia Bonomelli, Valentina Celis, Gian Lombardi and Johanna Mártiz * \\ Departamento de Fruticultura y Enología, Pontificia Universidad Católica de Chile, Vicuna Mackenna 4860, \\ Macul 7820436, Chile; cbonomel@uc.cl (C.B.); vacelis@uc.cl (V.C.); glombardi@uc.cl (G.L.) \\ * Correspondence: jmartiz@uc.cl; Tel.: +562-2354-4159
}

Received: 19 March 2018; Accepted: 3 May 2018; Published: 4 May 2018

\begin{abstract}
Salinity is one of the major factors limiting avocado yield, primarily due to the high concentration of ions in irrigation water. An experiment was conducted on 2 year old avocado plants (Persea americana Mill.) cv. Hass, grafted onto Duke 7 clonal rootstock growing in pots, to determine the effect of salt stress on growth, as well as physiological and biochemical responses, and the effect of seaweed extract (Ascophyllum nodosum) on salinity stress. Treatments consisted of different types of irrigation water: distilled water, $9 \mathrm{mM} \mathrm{NaCl}$ water, distilled water $+2.25 \mathrm{~mL}$ of seaweed extract, $9 \mathrm{mM} \mathrm{NaCl}$ water $+2.25 \mathrm{~mL}$ of seaweed extract and, $9 \mathrm{mM} \mathrm{NaCl}$ water $+1.5 \mathrm{~mL}$ of seaweed extract. The irrigation treatment was applied every 15 days for 8 months. Treatments with salt reduced plant growth by approximately $50 \%$ of the fresh weight of all avocado plant tissues. Seaweed extract reduced the effects of abiotic stress only at an early stage, and increased potassium $(\mathrm{K})$ and calcium (Ca) concentrations in leaves.
\end{abstract}

Keywords: biostimulants; abiotic stress; plant growth; root partitioning

\section{Introduction}

Avocado (Persea americana Mill.) is considered a salt-sensitive species, especially the Mexican and Guatemalan races (var. drymifolia and guatemalensis respectively). The rate of cell expansion in growing tissues and the degree of stomatal aperture in leaves are reduced due to the osmotic effect of salts. A reduction of photosynthesis is caused by a reduction in stomatal conductance of $\mathrm{CO}_{2}$, which together with the slower formation of photosynthetic leaf area, reduces the flow of assimilates to the meristematic and growing tissues of the plant i.e., leaves and roots, although leaves are often more affected than roots, due to the ability to efflux excessive salts and control uptake in order to avoid toxicity [1]. In Chile, salinity is a limiting condition affecting avocado productivity, with this crop being considered the most salt sensitive of the cultivated fruit trees [2]. Salinity significantly reduces growth, productivity, and quality of crops by affecting their physiology and biochemical attributes [3]. For example, osmotic stress in the initial stage of salinity stress in wheat (Triticum aestivum) caused various physiological changes, such as the interruption of membranes, nutrient imbalance, and impaired ability to detoxify reactive oxygen species, differences in antioxidant enzymes, decreased photosynthetic activity, and a decrease in stomatal opening [4]. In cherry tomato (Lycopersicon esculentum), high salinity decreased the concentration of leaf proteins, total carotenoids, chlorophyll, soluble sugars, and starch and phenolic contents [5]. With the increase in uptake of sodium $\left(\mathrm{Na}^{+}\right)$and chlorine $\left(\mathrm{Cl}^{-}\right)$, the nitrogen $(\mathrm{N})$, calcium $\left(\mathrm{Ca}^{2+}\right)$, and potassium $\left(\mathrm{K}^{+}\right)$concentration and with the decreased in $\mathrm{Mg}^{2+}$ concentration, the nutritional balance of the plants is upset, which ultimately reduces their growth [6]. 
Seaweed extract has been reported to alleviate a variety of abiotic stresses, including drought, salinity, and temperature [7]. One of the species most commonly used in the extract base is Ascophyllum nodosum (L.) Le Jolis, a brown seaweed characteristic of the mild intertidal zones of the North Atlantic's temperate rocky shores. Ascophyllum nodosum is concentrated along the coast of Brittany, which, along with Norway, is a major site for A. nodosum harvesting along Europe's rocky shores [8]. The response of this seaweed extract is mediated via an intricate network of signals that perceive stress and set in motion molecular, biochemical, and physiological processes that may be unique to each stress [9]. Seaweed extract also increases the endogenous concentrations of stress-related molecules, such as cytokinins, proline, and antioxidants in treated plants [10]. Proline, an essential amino acid and signaling molecule, acts as a plant growth regulator by activating various signaling processes [11]. Studies have reported that proline alleviates the adverse effects of salt stress on rice seedlings [12]. Exogenous biostimulants have been found to increase fruit retention and marketable yield in various fruit crops, including some avocado cultivars [13].

However, plants naturally develop various physiological and biochemical mechanisms to survive in soils with high salt concentrations [14]. The main mechanism is to minimize salt entry and reduce the salt concentration in the cytosol [15]. This mechanism includes ion homeostasis and compartmentalization, ion transport and uptake, biosynthesis of osmoprotectants and compatible solutes, and synthesis of polyamines. Protecting enzyme denaturation is another way to combat the harmful effects of ionic toxicity [16].

Due to the increased establishment of avocado orchards in saline soils in Chile, it is important to study management strategies that could alleviate its effects on growth and yield. The objectives of this study were to determine the effect of salt stress on growth and nutrient concentration in avocado plants, and also to study if the application of seaweed extract (Ascophyllum nodosum) through irrigation can alleviate salinity stress. Our hypothesis were that saline stress will negatively affect nutrient uptake and plant growth, both below and above ground, and that the addition of seaweed extract will, at least in part, compensate these negative effects.

\section{Materials and Methods}

\subsection{Plant Material and Environmental Conditions}

The experiment was conducted on 2 year old avocado plants (Persea americana Mill.) cv. Hass grafted onto Duke 7 clonal rootstock. Avocado plants were established on commercial soil $\mathrm{pH}=6$, where all nutrients were at sufficient levels and did not limit the growth of the plants. Plants were maintained in $28 \mathrm{~L}$ plastic pots under a white mesh ( $40 \%$ shade) at a research site at the Pontificia Universidad Católica de Chile ( $\left.34^{\circ} 08^{\prime} \mathrm{S}, 70^{\circ} 43^{\prime} \mathrm{W}\right)$ for 8 months (October-May). The climate of the area is a Mediterranean type with rainy, cool, wet winters, and hot, dry summers, with minimum average temperature of $10{ }^{\circ} \mathrm{C}$, and maximum average temperature of $28^{\circ} \mathrm{C}$. The average relative humidity of the period was $58.9 \%$ [17].

\subsection{Experimental Design and Treatments}

The experiment consisted on a complete randomized design with five treatments and six replicates (plants). Treatments were according to the type of irrigation water as follows: $\mathrm{T} 0=$ no salinity stress, irrigation with distilled water; TS = salinity stress, irrigation with $9 \mathrm{mM} \mathrm{NaCl}$ water $(\mathrm{EC}=1.0 \mathrm{dS} / \mathrm{cm}$, $\mathrm{pH}=8) ; \mathrm{T} 0+2.25 \mathrm{SW}=$ no salinity stress with addition of algae extract, irrigation with distilled water $+2.25 \mathrm{cc}$ of seaweed extract; TS $+2.25 \mathrm{SW}=$ salinity stress with addition of algae extract, irrigation with $9 \mathrm{mM} \mathrm{NaCl}$ water $+2.25 \mathrm{cc}$ of seaweed extract; and TS $+1.5 \mathrm{SW}=$ salinity stress with addition of algae extract in lower dose, irrigation with $9 \mathrm{mM} \mathrm{NaCl}$ water $+1.5 \mathrm{cc}$ of seaweed extract. Irrigation frequency during the experiment was determined based on tensiometers arranged in each pot, in which the soil moisture was maintained at field capacity, but seaweed extracts (SW) were applied only every 15 days. 


\subsection{Measurements on Plant Growth}

Shoot height $(\mathrm{cm})$, change in stem diameter $(\mathrm{mm})$, numbers of leaves and percentage of necrosis were evaluated monthly for 8 months. At the end of the study period, all plants were harvested. Fine $(<1 \mathrm{~mm})$ and main roots were separated from the soil by applying abundant water at low pressure to avoid the loss of fine roots. Aerial parts were separated from the roots, and the fresh weights of the leaves, shoots, and roots were determined using a digital balance (Shanghai SP-300, Shanghai Huade Weighing Apparatus Co., Shanghai, China). Then, tissues were oven dried at $70{ }^{\circ} \mathrm{C}$ for 3 days (to a constant weight), and the dry weights of the leaves and the shoots were determined using an electronic balance (Transcell ESW-5M, Transcell Technology, Inc., Buffalo Grove, IL, USA). Also, fine versus main root partitioning was expressed as a percentage of the total root system.

\subsection{Measurements on Nutrient Composition}

After plants were harvested for biomass determination, 20 leaf samples, 15-20 cm long pieces of seasonal shoots, and $150 \mathrm{~g}$ of roots per replicate (pant) were rinsed in deionized water and then dried at $70{ }^{\circ} \mathrm{C}$ in an oven for $48 \mathrm{~h}$, until they reached a constant weight. Dry tissue samples were ground, and $\mathrm{N}, \mathrm{K}, \mathrm{Ca}, \mathrm{Cl}$, and $\mathrm{Na}$ concentrations were measured using the method described by Page [18]. The $\mathrm{N}$ concentrations were determined with a LECO CNS-2000 Macro Elemental Analyzer (Leco, Michigan, MI, USA). The K, Ca, and Na concentrations were determined by dry combustion at $500{ }^{\circ} \mathrm{C}$ until the organic components were converted to ash. For $\mathrm{K}, \mathrm{Ca}$, and $\mathrm{Na}$, the tissue samples' ashes were dissolved in $\mathrm{HCl}(2 \mathrm{M})$, and the concentrations were determined with an atomic absorption spectrophotometer (Varian SpectraAA 220 FS, Varian Techtron Pty. Limited, Victoria, Australia).

The $\mathrm{N}$ content was calculated by multiplying the dry weight by the $\mathrm{N}$ concentration of each plant organ aboveground. $\mathrm{Na}$ and $\mathrm{Cl}$ contents were calculated by multiplying the dry weight of the roots by the $\mathrm{Na}$ and $\mathrm{Cl}$ concentration of the roots, and the $\mathrm{K}^{+} / \mathrm{Na}^{+}$ratio was calculated by dividing the $\mathrm{K}$ concentration in the leaves by the Na concentration in the leaves.

Finally, to explore if proline could be related to a response of avocado plants to saline stress, the proline content in fine and main roots of the T0 (no salinity stress) and TS (salinity stress) treatment was determined. For this, $0.15 \mathrm{~g}$ of dry roots were combined with $6 \mathrm{~mL}$ of $3 \%$ sulfosalicylic acid and then shaken for $30 \mathrm{~min}$. Subsequently, the homogenate was filtered on Whatman filter paper no. 1. An aliquot of $2 \mathrm{~mL}$ was added to $2 \mathrm{~mL}$ of ninhydrin acid and $2 \mathrm{~mL}$ of glacial acetic acid, and incubated at $95{ }^{\circ} \mathrm{C}$ for $1 \mathrm{~h}$. After that, the solution was placed in a cold bath with $4 \mathrm{~mL}$ of toluene, and vigorously shaken for 15-20 s. The organic phase was recovered, and the absorbance was then read at $520 \mathrm{~nm}$. The method used was based on Bates et al. [19].

\subsection{Data Analysis}

The effects of treatments on plant growth, leaf necrosis, and nutrient content were analyzed with a one-way ANOVA, and mean differences were determined with the Tukey-Kramer $(p<0.05)$ test. All statistical analyses were performed using STATISTICA (Version 7, Data Analysis and Statistical Software, Dell, Victoria, Australia).

\section{Results}

\subsection{Effect of Salt Irrigation and Seaweed Extract (SW) on Growth Parameters and Leaf Necrosis on Avocado Plants}

Regarding plant growth during the study period, at 30 days, treatments without salt stress and the one with salt stress and the higher dose of SW (2.25 cc of seaweed extract) produced plants that were significantly taller than those exposed to treatments with salt without the SW, or with the lower dose of the SW (1.5 cc of seaweed extract) (Figure 1). However, these differences changed over time, and only the treatments without salt stress ended up, in the study (day 240), being taller than those in the other treatments (Figure 1, Table 1). The differences in leaf numbers also changed in time. 
At 30 days, plants with salt stress had significantly less leaves than all the treatments without the stress $(\mathrm{TS}=85 \pm 15.7$ leaves, versus $\mathrm{T} 0=131 \pm 8.5, \mathrm{~T} 0+2.25 \mathrm{SW}=125 \pm 9, \mathrm{TS}+2.25 \mathrm{SW}=123 \pm 12.7$, $\mathrm{TS}+1.5 \mathrm{SW}=121 \pm 6.8$ ), but by the end of the experiment, only the treatments without salt stress had significantly more leaves than the treatment with salt stress (Table 1).

At the end of the study, stem diameter showed the same trend that plant height and leaf number (Table 1), and in the case of leaf necrosis, the treatments without salt stress showed significantly less damage $(p<0.01)$ than treatments with salt stress, regardless of the addition of SW (Table 1).

By the end of the experiment, the negative effects of salt stress were also evident in relation to plant mass, both above- and belowground. The dry weight of the aerial part (leaves and stems), roots and for the entire plant in the treatments without the stress (T0 and $\mathrm{T} 0+2.25 \mathrm{SW}$ ) were always significantly higher than treatments with saline irrigation, regardless of the addition of SW (Table 2. For the aboveground part, there was a trend for a higher mass in the salt stress with the addition SW $(\mathrm{TS}+2.25 \mathrm{SW}$ and TS $+1.5 \mathrm{SW})$ than without it (TS), but these differences were not significant (Table 2).

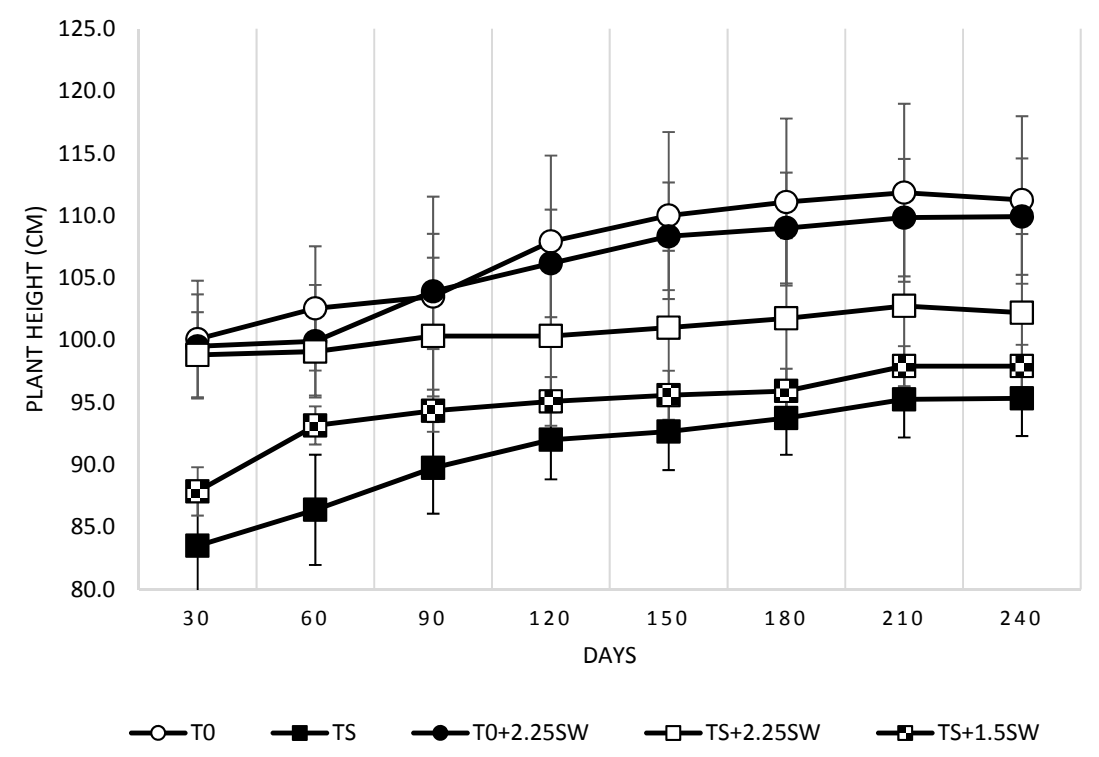

Figure 1. Changes in plant height in 2 year old Hass avocado plants grown in pot subjected to different treatments (T0: distilled water, TS: saline water $(9 \mathrm{mM} \mathrm{NaCl}), \mathrm{T} 0+2.25 \mathrm{SW}$ : distilled water + $2.25 \mathrm{~mL}$ seaweed, $\mathrm{TS}+2.25 \mathrm{SW}$ : saline water $(9 \mathrm{mM} \mathrm{NaCl})+2.25 \mathrm{~mL}$ seaweed $\mathrm{T} 0+1.5 \mathrm{~mL}$ seaweed), measurements were made every 30 days until completion at 240 days of study, with 6 replicates per treatment.

Table 1. Growth parameters and leaf necrosis percentage at the end of the study period (240 days) of 2 year old Hass avocado plants grown in pot under different treatments (T0: distilled water, TS: saline water $(9 \mathrm{mM} \mathrm{NaCl}), \mathrm{T} 0+2.25 \mathrm{SW}$ : distilled water $+2.25 \mathrm{~mL}$ seaweed, $\mathrm{TS}+2.25 \mathrm{SW}$ : saline water $(9 \mathrm{mM}$ $\mathrm{NaCl})+2.25 \mathrm{~mL}$ seaweed $\mathrm{T} 0+1.5 \mathrm{~mL}$ seaweed) for 240 days, with 6 replicates per treatments.

\begin{tabular}{|c|c|c|c|c|}
\hline \multirow[t]{3}{*}{ Treatments } & & Parameters & & \multirow{3}{*}{ Necrosis $(\%)$} \\
\hline & \multirow{2}{*}{$\begin{array}{c}\text { Plant } \\
\text { Height (mm) }\end{array}$} & \multirow{2}{*}{$\begin{array}{c}\Delta \text { Stem Diameter } \\
(\mathrm{mm})\end{array}$} & \multirow{2}{*}{$\begin{array}{c}\text { Leaf } \\
\text { Number } \\
\end{array}$} & \\
\hline & & & & \\
\hline T0 & $112 \pm 6.72 \mathrm{a}$ & $1.9 \pm 0.75 \mathrm{a}$ & $148 \pm 8.55 \mathrm{a}$ & $8 \mathrm{~b}$ \\
\hline TS & $93 \pm 4.67 b$ & $0.2 \pm 0.58 b$ & $95 \pm 15.70 b$ & $24 \mathrm{a}$ \\
\hline $\mathrm{T} 0+2.25 \mathrm{SW}$ & $110 \pm 6.32 \mathrm{a}$ & $1.4 \pm 0.21 \mathrm{a}$ & $144 \pm 9.08 \mathrm{a}$ & $12 \mathrm{~b}$ \\
\hline $\mathrm{TS}+2.25 \mathrm{SW}$ & $101 \pm 1.71 \mathrm{ab}$ & $0.6 \pm 0.89 a b$ & $119 \pm 12.76 \mathrm{ab}$ & $25 a$ \\
\hline $\mathrm{TS}+1.5 \mathrm{SW}$ & $97 \pm 3.02 \mathrm{ab}$ & $0.8 \pm 0.28 \mathrm{ab}$ & $117 \pm 6.87 \mathrm{ab}$ & $23 a$ \\
\hline
\end{tabular}

Means with different letters indicate significant differences (Tukey test, $p<0.05$ ). 
Table 2. Aboveground (leaves and steam) and belowground (roots) of 2 year old Hass avocado plants grown in pot under different salt and seaweed extract conditions (T0: distilled water, TS: saline water $(9 \mathrm{mM} \mathrm{NaCl}), \mathrm{T} 0+2.25 \mathrm{SW}$ : distilled water $+2.25 \mathrm{~mL}$ seaweed, $\mathrm{TS}+2.25 \mathrm{SW}$ : saline water $(9 \mathrm{mM} \mathrm{NaCl})$ $+2.25 \mathrm{~mL}$ seaweed $\mathrm{T} 0+1.5 \mathrm{~mL}$ seaweed) for 240 days, with 6 replicates per treatments.

\begin{tabular}{ccc}
\hline Treatments & Aboveground & Belowground \\
\hline T0 & $155 \pm 9.78 \mathrm{a}$ & $48 \pm 4.57 \mathrm{a}$ \\
TS & $67 \pm 7.10 \mathrm{~b}$ & $19 \pm 1.39 \mathrm{~b}$ \\
T0 + 2.25SW & $137 \pm 6.63 \mathrm{a}$ & $44 \pm 4.02 \mathrm{a}$ \\
TS + 2.25SW & $83 \pm 6.35 \mathrm{~b}$ & $18 \pm 1.72 \mathrm{~b}$ \\
TS + 1.5SW & $78 \pm 3.42 \mathrm{~b}$ & $15 \pm 0.98 \mathrm{~b}$ \\
\hline
\end{tabular}

Means with different letters indicate significant differences (Tukey test, $p<0.05$ ).

As with the dry weight, the effect of salt stress on fresh weight was also significant, with saline irrigation plants decreasing, on average, by $50 \%$ compared to control plants (Figure 2). In the case of the roots, mean values for TS and T0 were $150 \mathrm{~g} \mathrm{plant}^{-1}$ versus $300 \mathrm{~g} \mathrm{plant}^{-1}$, for shoots it was $153 \mathrm{~g}$ plant $^{-1}$ versus $273 \mathrm{~g} \mathrm{plant}^{-1}$, and leaves were $88 \mathrm{~g} \mathrm{plant}^{-1}$ and $165 \mathrm{~g} \mathrm{plant}^{-1}$, respectively.

Regarding fine versus main root fresh weight partitioning, fine roots for $\mathrm{T} 0$, $\mathrm{T} 0+2.25 \mathrm{SW}$, and TS $+2.25 \mathrm{SW}$ were $33 \% \pm 1.3,33 \% \pm 4.6$, and $31 \% \pm 3.6$ of the total root system respectively, which was significantly higher $(p=0.01)$ than the values for TS and TS $+1.5 S W$, which were $19 \% \pm 2.7$ and $20 \% \pm 3.5$, respectively.

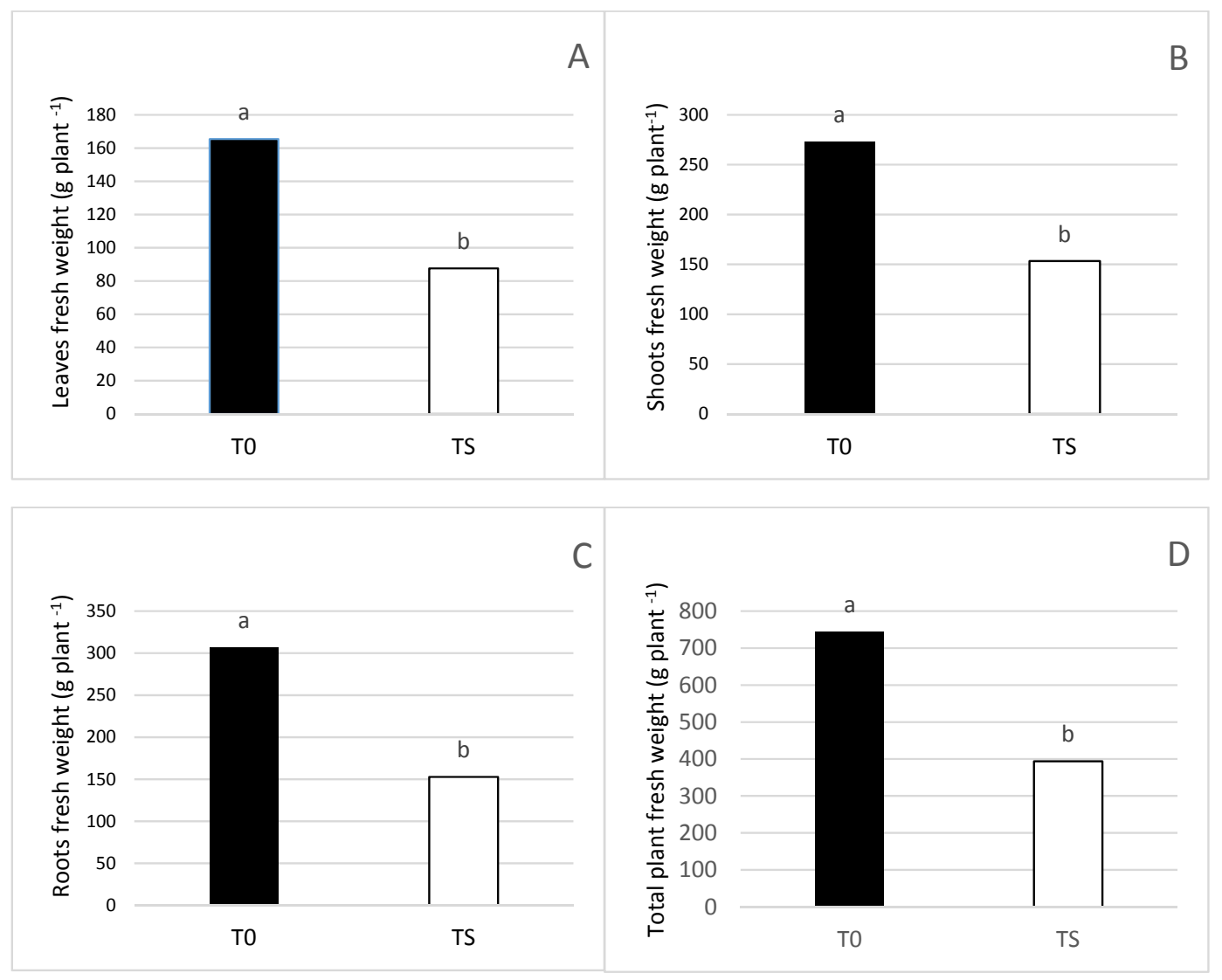

Figure 2. Fresh weight of (A) leaves; (B) shoots; (C) roots; and (D) total plant of 2 year old Hass avocado plants grown in pots subjected to T0 (distilled water) or TS (saline water $(9 \mathrm{mM} \mathrm{NaCl})$ ) treatment for 240 days, with 6 replicates per treatment. Means with different letters indicate significant differences between treatments (Tukey test $p<0.05$ ). 


\subsection{Effect of Salt Irrigation and Seaweed Extract (SE) on Nutrient Composition and Biochemical Parameters}

Regarding ion concentrations in leaves (Table 3), treatments with addition of SW (T0 + 2.25SW, $\mathrm{TS}+2.25 \mathrm{SW}$, and TS + 1.5SW) had higher concentrations of $\mathrm{K}^{+}$in the leaves, followed by the treatment without stress and no SW (T0), and with the treatment with stress and no SW (TS) presenting the lowest value (Table 3). In the case of $\mathrm{Ca}^{2+}$, plants with no stress and SW addition $(\mathrm{T} 0+2.25 \mathrm{SW}$ ) had significantly higher content than in the other treatments, and again, plants with stress and no SW addition (TS) having the lowest contents (Table 3).

Table 3. The ion concentration $\left(\mathrm{K}^{+}\right.$and $\left.\mathrm{Ca}^{2+}\right)$ in the leaves of 2 year old Hass avocado plants grown under different salt and seaweed extract (T0: distilled water, TS: saline water $(9 \mathrm{mM} \mathrm{NaCl}), \mathrm{T} 0+2.25 \mathrm{SW}$ : distilled water $+2.25 \mathrm{~mL}$ seaweed, $\mathrm{TS}+2.25 \mathrm{SW}$ : saline water $(9 \mathrm{mM} \mathrm{NaCl})+2.25 \mathrm{~mL}$ seaweed $\mathrm{T} 0+1.5 \mathrm{~mL}$ seaweed) for 240 days with 6 replicates per treatment.

\begin{tabular}{ccc}
\hline Treatments & \multicolumn{2}{c}{ Ion Concentration } \\
\hline & $\mathbf{K}^{+} \mathbf{( \% )}$ & $\mathbf{C a}^{\mathbf{2 +}} \mathbf{( \% )}$ \\
\hline T0 & $1.07 \pm 0.06 \mathrm{~b}$ & $1.10 \pm 0.21 \mathrm{bc}$ \\
TS & $0.93 \pm 0.03 \mathrm{c}$ & $0.88 \pm 0.10 \mathrm{c}$ \\
T0+2.25SW & $1.40 \pm 0.05 \mathrm{a}$ & $1.47 \pm 0.06 \mathrm{a}$ \\
TS+2.25SW & $1.47 \pm 0.08 \mathrm{a}$ & $1.07 \pm 0.12 \mathrm{bc}$ \\
TS+1.5SW & $1.50 \pm 0.10 \mathrm{a}$ & $0.97 \pm 0.26 \mathrm{~b}$ \\
\hline with different letters indicate significant differences (Tukey test, $p<0.05)$.
\end{tabular}

$\mathrm{N}$ content in the aboveground part (Figure 2) was influenced by saline stress and addition of SW in large doses. The higher $\mathrm{N}$ contents were in the no saline stress treatments ( $\mathrm{T} 0$ and $\mathrm{T} 0+2.25 \mathrm{SW}$ ) and in the saline stress with a high SW dose addition (TS $+2.25 \mathrm{SW}$ ), while significantly lower values were found in the saline stress treatment (TS) and saline stress with a low SW dose addition $(\mathrm{TS}+1.5 \mathrm{SW})$ (Figure 3).

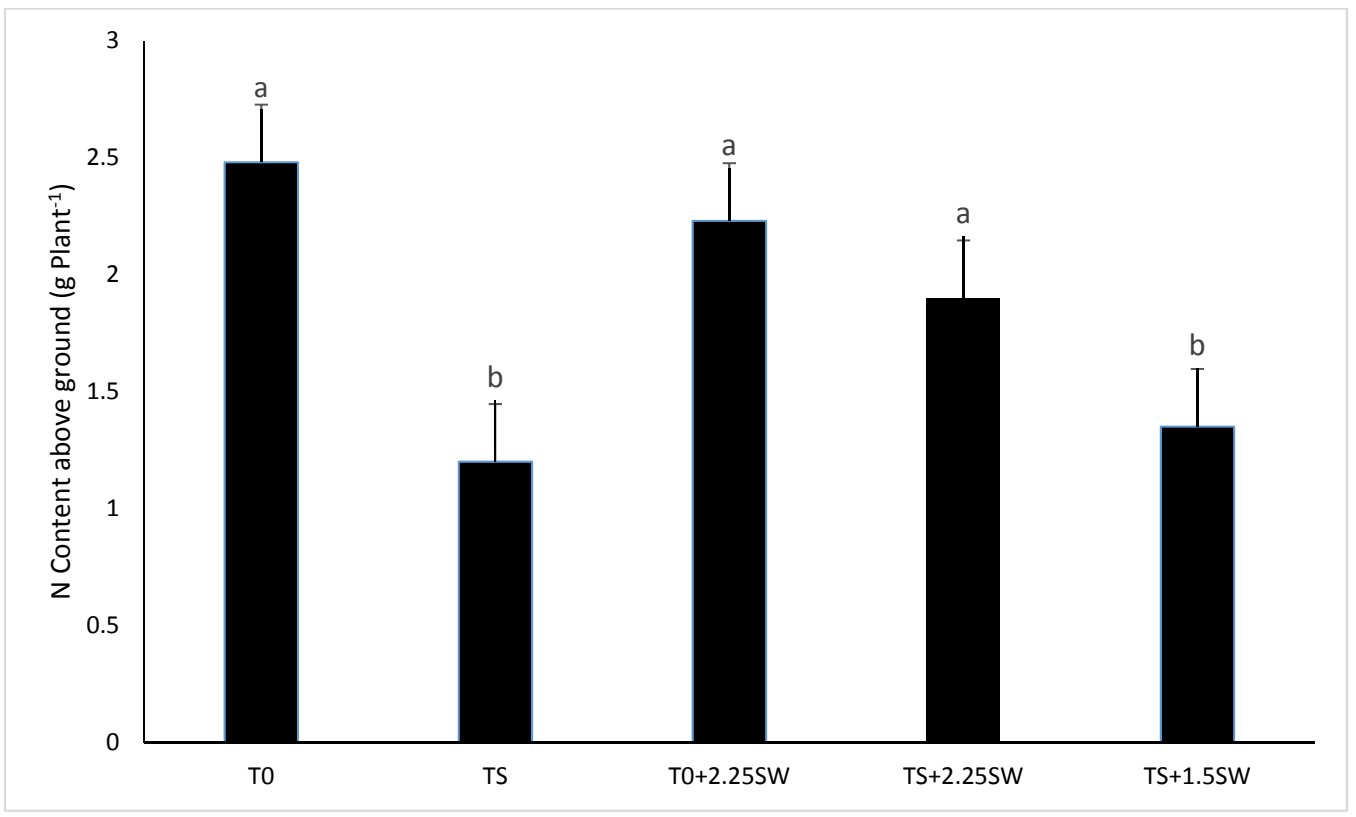

Figure 3. N content above ground in 2 year Hass avocado plants grown in pot for 240 days with different treatments (T0: distilled water, TS: saline water $(9 \mathrm{mM} \mathrm{NaCl}), \mathrm{T} 0+2.25 \mathrm{SW}$ : distilled water + $2.25 \mathrm{~mL}$ seaweed, $\mathrm{TS}+2.25 \mathrm{SW}$ : saline water $(9 \mathrm{mM} \mathrm{NaCl})+2.25 \mathrm{~mL}$ seaweed $\mathrm{T} 0+1.5 \mathrm{~mL}$ seaweed) with 6 replicates per treatment. Means with different letters indicate significant differences between treatments (Tukey test $p<0.05$ ). 
Regarding the $\mathrm{K}^{+} / \mathrm{Na}^{+}$ratio in leaves, only an effect of saline stress was observed, with plants in the treatments without stress ( $\mathrm{T} 0$ and $\mathrm{T} 0+2.25 \mathrm{SW}$ ) having a larger ratio than the treatments with stress regardless the addition of SW (TS, TS $+2.25 \mathrm{SW}$ and TS $+1.5 \mathrm{SW}$ ) (Figure 4).

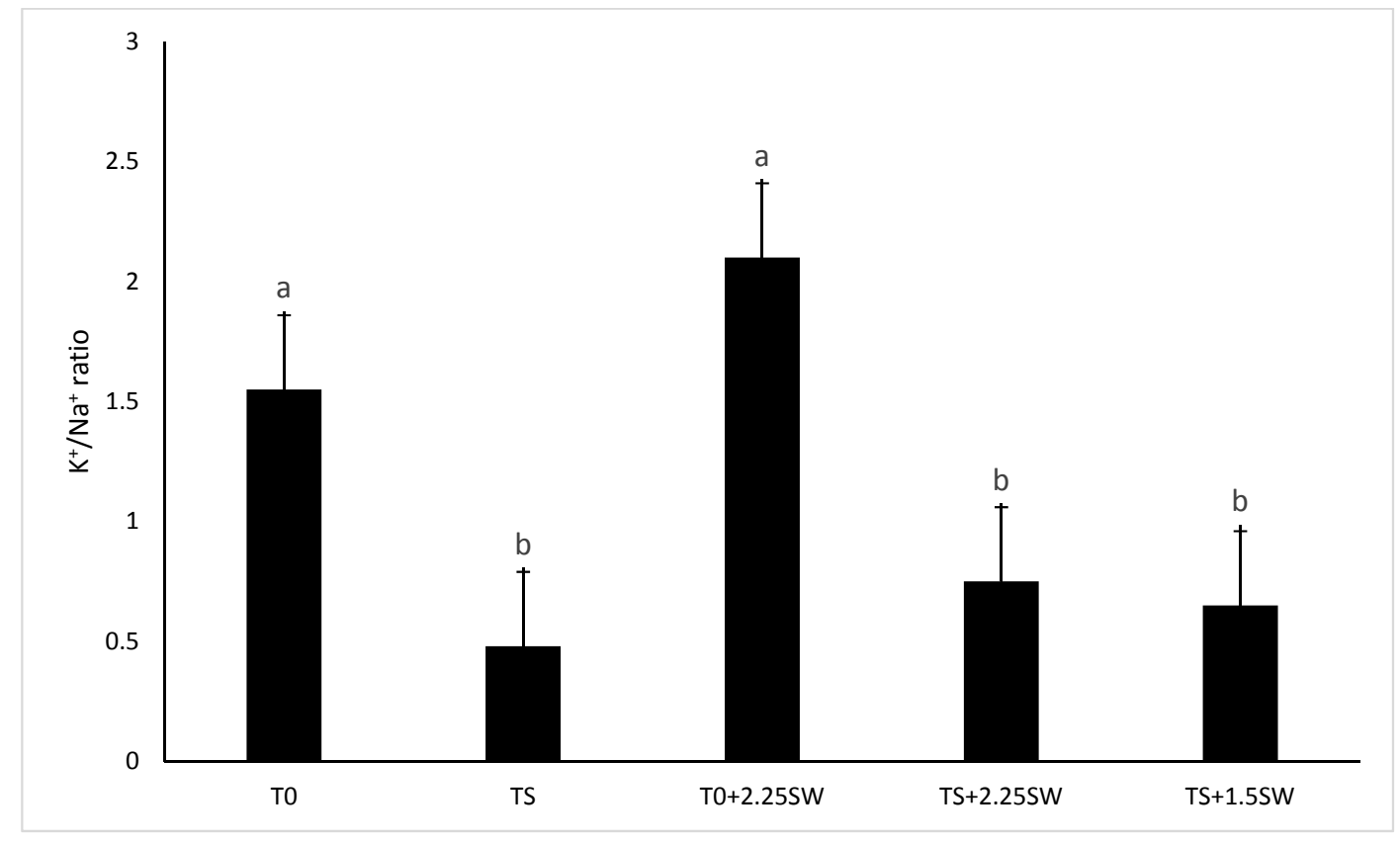

Figure 4. The $\mathrm{K}^{+} / \mathrm{Na}^{+}$ratio in the leaves on 2 year Hass avocado plant grown in pot for 240 days with different treatments (T0: distilled water, TS: saline water $(9 \mathrm{mM} \mathrm{NaCl}), \mathrm{T} 0+2.25 \mathrm{SW}$ : distilled water + $2.25 \mathrm{~mL}$ seaweed, $\mathrm{TS}+2.25 \mathrm{SW}$ : saline water $(9 \mathrm{mM} \mathrm{NaCl})+2.25 \mathrm{~mL}$ seaweed $\mathrm{T} 0+1.5 \mathrm{~mL}$ seaweed) with 6 replicates per treatment. Means with different letters indicate significant differences between treatments (Tukey test $p<0.05$ ).

$\mathrm{Na}^{+}$and $\mathrm{Cl}^{-}$content in roots also showed a clear effect of saline stress, with roots of plants in the treatments without stress (T0 and T0 $+2.25 \mathrm{SW}$ ) having a lower content of $\mathrm{Na}^{+}$and $\mathrm{Cl}^{-}$while the treatments with stress (TS, TS $+2.25 \mathrm{SW}$ and TS $+1.5 \mathrm{SW}$ ) having larger amounts of these elements (Figure 5).

In relation to the potential effects of proline in the response to saline stress, we found that proline in fine roots of plants without stress (T0) was $53 \pm 0.28 \mu \mathrm{g} \mathrm{g}^{-1}$, significantly lower $(p=0.00001)$ than in the saline stressed plants (TS), having $67 \pm 0.49 \mu \mathrm{g} \mathrm{g}^{-1}$. However, no significant difference in proline concentration between these treatments was found in the main roots. 


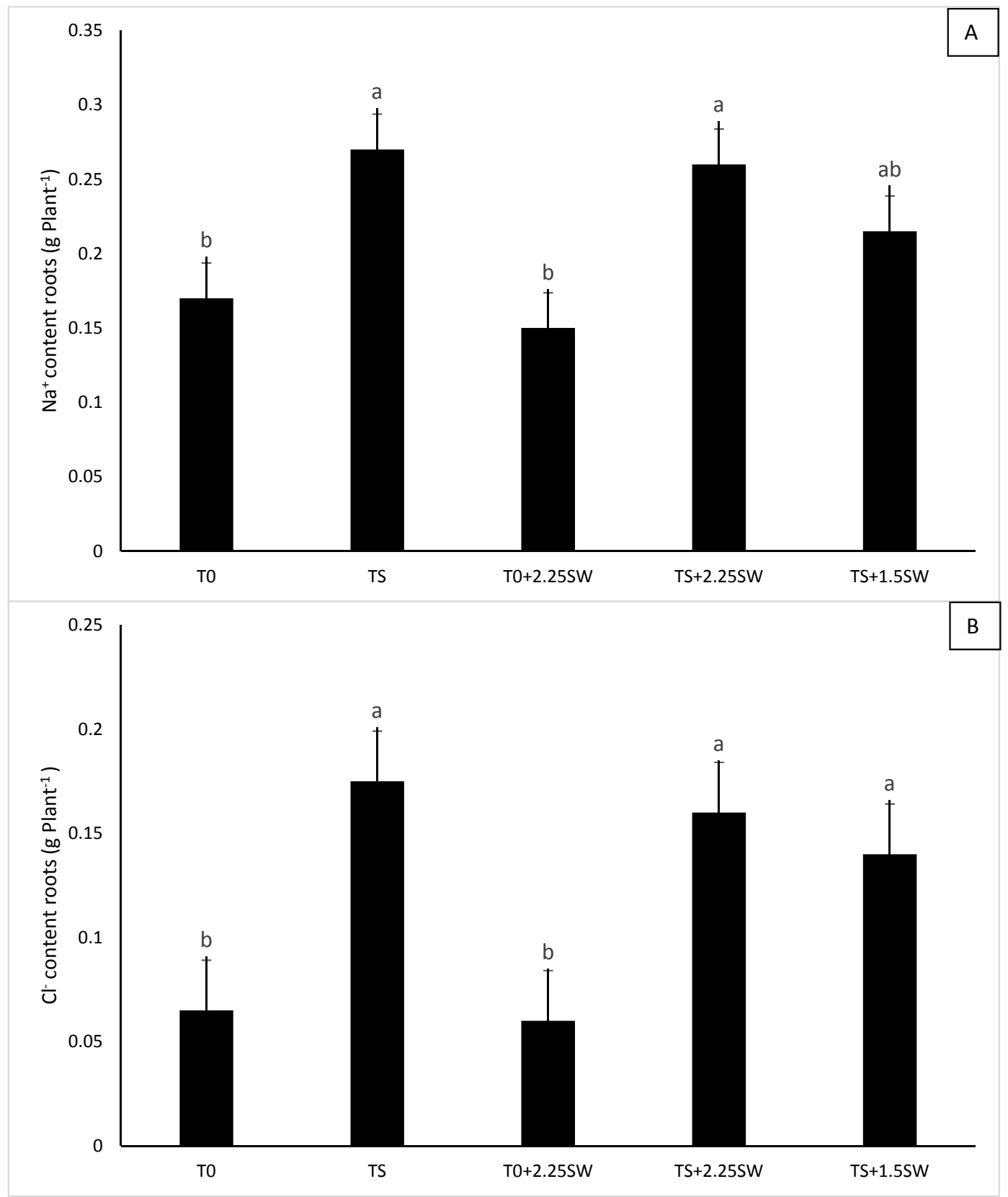

Figure 5. (A) $\mathrm{Na}^{+}$and (B) $\mathrm{Cl}^{-}$content in roots of 2 year Hass avocado plant grown in pot for 240 days with different treatments (T0: distilled water, TS: saline water $(9 \mathrm{mM} \mathrm{NaCl}), \mathrm{T} 0+2.25 \mathrm{SW}$ : distilled water $+2.25 \mathrm{~mL}$ seaweed, $\mathrm{TS}+2.25 \mathrm{SW}$ : saline water $(9 \mathrm{mM} \mathrm{NaCl})+2.25 \mathrm{~mL}$ seaweed $\mathrm{T} 0+1.5 \mathrm{~mL}$ seaweed) for 240 days, with 6 replicates per treatment. Means with different letters indicate significant differences between treatments (Tukey test $p<0.05$ ).

\section{Discussion}

Saline soils and saline irrigation constitute serious problems for vegetable crop production because saline conditions are known to suppress plant growth [20]. In the present study, we also found that salinity adversely and significantly affected plant growth. Generally, salt stress can delay and inhibit plant growth differentiation of plant tissue, and reduce the fresh weight of leaf, stem, and root tissue with increased salt [21]. In this experiment, it was observed that saline irrigation decreased, by $50 \%$, the fresh weight of all plant tissues compared to samples watered with distilled water, with $\mathrm{T} 0$ having a significantly different in final fresh weight total compared to TS. This finding is consistent with 
Munns and Rawson [22], who observed an inhibition of vegetative development of the shoots and roots as the primary response to salt stress, as was observed in the present experiment, in which the roots and stems showed $50 \%$ and $56 \%$ less fresh weight in saline conditions compared to the control.

Salt stress not only affects growth parameters in plants. Hameed and Ashraf [14] noted that salinity adversely affected photosynthesis-related parameters, such as stomatal conductance. Plants have developed mechanisms of adaptation to stress conditions. Osmotic-adjusting substances play an important role for plants during the progress of growth, development, and reproduction in salt and drought stress [23].

Analyzing the differences in growth of plants subjected to different treatments of the experiment at 30 days, we observed a decrease in plant height and leaf number in TS compared to T0 $(17 \%$ and $36 \%$, respectively). Furthermore, the height of the plants and the number of leaves of TS $+1.5 \mathrm{SW}$ differed from those in T0 by $12 \%$ and $8 \%$, respectively. TS $+2.25 \mathrm{SW}$ was determined to present a difference from $\mathrm{T} 0$ of $1 \%$ in height and $6 \%$ in the number of leaves. Throughout the study period, T0 was found to always be the more effective treatment with respect to plant height, leaf number, and leaf area, while TS had the lowest values throughout the entire study.

Musyimi et al. [24] found that salinity reduced shoot height in approximately $74 \%$ of the avocado plants, while the stem diameter was also reduced by $63 \%$ in the control plants. A similar situation was observed by Bernstein et al. [25], in whose study the plant height and the stem diameter in avocado were 78 and $86 \%$ of the control, respectively. These values are comparable to our study, considering that at the end of the experiment, TS plant height was significantly different from $\mathrm{T} 0$ and $\mathrm{T} 0+2.25 \mathrm{SW}$, being $80 \%$ of the control.

For treatments with seaweed extract, no significant differences from the control were observed in final plant height, final leaf number, and change in the stem diameter. Seaweed extracts have been determined to be a complex mixture of organic and mineral components and plant hormones [26]. Numerous reports show the beneficial effects of seaweed extracts on shoot growth and crop yield, and seaweed extracts have been shown to alleviate a variety of abiotic stresses, including drought and salinity [7]. However, no benefits of seaweed extract were observed in relation to foliar necrosis, because the percentages of necrosis in the leaves in TS + 2.25SW and TS + 1.5SW were not significantly different from those in TS, and all were higher than in plants with no saline stress. Wahome et al. [27] observed that leaf injury increased with higher levels of $\mathrm{NaCl}$ in irrigation water, and that leaf injury was related to the duration of the treatment. In our study, all treatments with saline irrigation exhibited more than $20 \%$ necrosis. The pattern of necrosis appearing along the margins of older leaves was visually confirmatory of $\mathrm{Cl}^{-}$toxicity [28]. Mickelbart et al. [29] observed that the leaves that had the highest $\mathrm{Cl}^{-}$concentrations also had the most severe necrosis.

Furthermore, vegetative growth parameters could be explained due to a greater availability of soil nitrogen or a greater capacity to capture it by the roots. $\mathrm{T} 0, \mathrm{~T} 0+2.25 \mathrm{SW}$ and $\mathrm{TS}+2.25 \mathrm{SW}$ were found to have a significantly higher content of $\mathrm{N}$ in the aerial parts than TS and TS + 1.5SW. This difference may have occurred because the seaweed extract has proline. Mansour [30] proposed that another function of proline is the maintenance of membrane and protein stability, as well as growth and provisions of a store of carbon, nitrogen, and energy.

It should be noted that the aerial part is often related to the root part [31]. Du Jardin [32] observed that proline increases tissue concentrations and the root-to-shoot transport of micronutrients. Analysis of the root partition, expressed as a percentage of the total root system, revealed the same pattern as in the nitrogen content, wherein the fine roots of $\mathrm{T} 0, \mathrm{~T} 0+2.25 \mathrm{SW}$, and $\mathrm{TS}+2.25 \mathrm{SW}$ were approximately $30 \%$ of the total root mass. This percentage was significantly larger from that found in TS and TS $+1.5 \mathrm{SW}$, whose fine roots corresponded to $15 \%$ of the total root mass. Inhibition of root growth and root proliferation, if occurring under stress, could considerably reduce the surface area of fine roots, and hence, the uptake capacity of the root system. This return might reduce nutrient supply to the shoot. Additionally, a reduction in the root tissue under stress might also result in reduced transport of growth regulators from the root to the shoot, which may affect shoot growth 
and productivity [33]. Thus, a reduced root tissue would impact directly the aerial part of the plant, as observed in this study.

In relation to the ion concentrations, Shahbaz et al. [34] observed that salt stress adversely affected plant growth, gas exchange characteristics, and chlorophyll fluorescence, as well as the $\mathrm{Ca}^{2+}$ and $\mathrm{K}^{+}$ ions in eggplant cultivars under control and saline regimes. Grattan and Grieve [35] observed that salinity dominated by $\mathrm{Na}^{+}$and $\mathrm{Cl}^{-}$not only reduced $\mathrm{Ca}^{2+}$ and $\mathrm{K}^{+}$availability, but also reduced $\mathrm{Ca}^{2+}$ and $\mathrm{K}^{+}$transport and mobility to growing parts of the plants, affecting the quality of both vegetative and reproductive organs. The results of this study showed that salinity caused a significant reduction in the ion concentration in the leaves with respect to unstressed plants. However, with respect to $\mathrm{K}^{+}$, all the treatments that contained seaweed extract had significantly more $\mathrm{K}^{+}$than unstressed plants.

In the case of $\mathrm{Ca}$ in the leaves, all treatments had higher concentrations of $\mathrm{Ca}^{2+}$ in the leaves compared to TS. However, only T0 $+2.25 \mathrm{SW}\left(1.47 \% \mathrm{Ca}^{2+}\right)$ was significantly greater than T0 $\left(1.10 \% \mathrm{Ca}^{2+}\right)$.

Shahbaz et al. [34] observed that potassium levels in the stem increased in treatments with foliar proline. Thus, in our study, significant differences in the concentration of ions in the leaves on treatments with seaweed extract could be attributed to the external input of the seaweed extract for proline, calcium, and potassium content (Table 4), or it may be explained due to the presence of a greater quantify of fine roots, which make a larger and better nutrient uptake surface.

Table 4. Chemical composition of seaweed extract (\%, $\mathrm{mg} / \mathrm{kg}$ and $\mu \mathrm{g} / \mathrm{g}$ of dry weight).

\begin{tabular}{cccc}
\cline { 2 - 4 } Element & \multicolumn{1}{c}{ Value } \\
\cline { 2 - 4 } $\mathrm{P}$ & $\%$ & 0.03 \\
$\mathrm{~K}$ & $\%$ & 2.99 \\
$\mathrm{Ca}$ & $\%$ & 0.05 \\
$\mathrm{Mg}$ & $\%$ & 0.1 \\
$\mathrm{Cu}$ & $\mathrm{mg} / \mathrm{kg}$ & 1.28 \\
$\mathrm{Zn}$ & $\mathrm{mg} / \mathrm{kg}$ & 6.6 \\
$\mathrm{Fe}$ & $\mathrm{mg} / \mathrm{kg}$ & 19.5 \\
$\mathrm{Mn}$ & $\mathrm{mg} / \mathrm{kg}$ & 3.18 \\
$\mathrm{~B}$ & $\mathrm{mg} / \mathrm{kg}$ & 4.14 \\
$\mathrm{Proline}$ & $\mu \mathrm{g} / \mathrm{g}$ & 56.31 \\
\cline { 2 - 3 } Che Agroanalysis Laboratory in the Pontificia Universidad Catolica de Chile.
\end{tabular}

In addition, when analyzing the $\mathrm{K}^{+} / \mathrm{Na}^{+}$ratio in the leaves, we observed that all treatments with saline irrigation had significantly lower ratios than treatments watered with distilled water. The interaction between internal $\mathrm{K}^{+}$and $\mathrm{Na}^{+}$has been suggested to be an important factor in the determination of salt tolerance in many plant species. Silveira et al. [36] observed that $\mathrm{Na}^{+}$is transferred from the roots to the stems and the leaves in the transpiration stream, where it finally accumulates to toxic levels in the older leaves. Therefore, despite the external input of $\mathrm{K}^{+}$by the seaweed extract, $\mathrm{Na}^{+}$levels in treatments with saline irrigation (TS, TS $+2.25 \mathrm{SW}$, TS $+1.5 \mathrm{SW}$ ) significantly reduced the $\mathrm{K}^{+} / \mathrm{Na}^{+}$ratio compared to $\mathrm{T} 0$ and $\mathrm{T} 0+2.25 \mathrm{SW}$.

However, the accumulation of $\mathrm{Na}^{+}$in the leaves is not necessarily a negative situation. Pardossi et al. [37] observed that the accumulation of the $\mathrm{Cl}^{-}$and $\mathrm{Na}^{+}$ions in plant tissues under salinity has been associated with osmotic adaptation. This finding led us to investigate the contents of $\mathrm{Na}^{+}$and $\mathrm{Cl}^{-}$in the root system of the plant (Figure 5). With respect to the $\mathrm{Na}^{+}$content, TS and TS $+2.25 \mathrm{SW}$ had significantly higher $\mathrm{Na}^{+}$content than $\mathrm{T} 0$ and $\mathrm{T} 0+2.25 \mathrm{SW}$. A similar situation occurred with the $\mathrm{Cl}^{-}$content. Rubinigg et al. [38] observed that the roots are the first place where adjustment mechanisms and growth regulations are triggered to cope with stress. However, our study did not observe any resistance mechanism because the biomass of the aerial part at the end of the study period in all saline treatments (TS, TS $+2.25 \mathrm{SW}$, TS $+1.5 \mathrm{SW}$ ) was significantly lower than in 
$\mathrm{T} 0$ and $\mathrm{T} 0+2.25 \mathrm{SW}$ (Table 1). Something similar has been reported [39] regarding the alleged role of proline under saline stress, such as in wheat.

\section{Conclusions}

Salt stress adversely affects plant growth, both above, and belowground, as well as the $\mathrm{Ca}^{2+}$ and $\mathrm{K}^{+}$ionic concentration in avocado plants. In this study, saline irrigation $(9 \mathrm{mM} \mathrm{NaCl})$ reduced, by approximately $50 \%$, the fresh and dry weight of all avocado plant tissues.

The application of seaweed extract reduced the effects of saline stress in plant height in the first 30 days after the application of the stress treatment, but had no effect over the other plant growth parameters. Nevertheless, the application of this seaweed extract could not reduce the adverse effects of saline stress for the entire study period.

Author Contributions: J.M. conceived, designed the experiments and contributed reagents/materials; G.L. performed the experiments; C.B. and V.C. analyzed the data and /analysis tools; J.M., C.B. and V.C. wrote the paper.

Conflicts of Interest: The authors declare no conflict of interest.

\section{References}

1. Alvarez, C.; Marrero, A.; Gallo, A.; Gonzalez, A. Physiological response of selected avocados (Persea americana) subjected to $\mathrm{NaCl}$ and $\mathrm{NaHCO}_{3}$ stress. Sci. Hortic. 2018, 237, 81-88. [CrossRef]

2. Haas, A.R.C. Effect of sodium chloride on Mexican, Guatemalan and West Indian avocado seedlings. Calif. Avocado Soc. Yearb. 1950, 34, 153-160.

3. Poltronieri, P.; Bonsegna, B.; De-Domenico, S.; Santino, A. Molecular mechanisms in plant abiotic stress responde. Field Veg. Crops Res. 2011, 48, 15-24. [CrossRef]

4. Rahnama, A.; James, R.A.; Poustini, K.; Munns, R. Stomatal conductance as a screen for osmotic stress tolerance in durum wheat growing in saline soil. Funct. Plant Biol. 2010, 37, 255-263. [CrossRef]

5. Al Hassan, M.; Martínez, M.; Ramos, F.J.; Boscaiu, M. Effects of Salt and Water Stress on Plant Growth and on Accumulation of Osmolytes and Antioxidant Compounds in Cherry Tomato. Not. Bot. Horti Agrobot. Cluj-Napoca 2015, 43, 1-11. [CrossRef]

6. Nandy, P.; Das, S.; Ghose, M.; Spooner-Hart, R. Effects of salinity on photosynthesis, leaf anatomy, ion accumulation and photosynthetic nitrogen use efficiency in five Indian mangroves. Wetl. Ecol. Manag. 2007, 15, 47-57. [CrossRef]

7. Craigie, J.S. Seaweed extract stimuli in plant science and agriculture. J. Appl. Phycol. 2011, 23, 371-393. [CrossRef]

8. Airoldi, L.; Beck, M. Oceanography and Marine Biology: An Annual Review; CRC Press: New York, NY, USA, 2007; Volume 45, pp. 345-405, ISBN 978-1-4200-5094-3.

9. Dos Reis, S.P.; Lima, A.M.; De Souza, C.R.B. Recent molecular advances on downstream plant responses to abiotic stress. Int. J. Mol. Sci. 2012, 13, 8628-8647. [CrossRef] [PubMed]

10. Fan, D.; Hodges, D.; Critchley, A.; Prithiviraj, B. A commercial extract of Brown Macroalga (Ascophyllum nodosum) affects yield and the nutritional quality of spinach in vitro. Commun. Soil Sci. Plant Anal. 2013, 44, 1873-1884. [CrossRef]

11. Yang, S.L.; Lan, S.S.; Gong, M. Hydrogen peroxide-induce proline and metabolic pathway of its accumulation in maize seedlings. J. Plant Physiol. 2009, 166, 1694-1699. [CrossRef] [PubMed]

12. Nounjan, N.; Theerakulpisut, P. Effects of exogenous proline and trehalose on physiological responses in rice seedlings during salt-stress and after recovery. Plant Soil Environ. 2012, 58, 309-315. [CrossRef]

13. Morales-Payan, J.P.; Candelas, C.D. Increasing Organic Avocado Fruit Yield Using an Ascophyllum nodosum Biostimulant and Fertilization. Acta Hortic. ISHS 2014, 1042, 121-124. [CrossRef]

14. Hameed, M.; Ashraf, M. Physiological and biochemical adaptations of Cynodon dactylon (L.) Pers. from the Salt Range (Pakistan) to salinity stress. Flora 2008, 203, 683-694. [CrossRef]

15. James, R.A.; Blake, C.; Byrt, C.S.; Munns, R. Major genes for $\mathrm{Na}^{+}$exclusion, $\mathrm{Nax} 1$ and Nax2 (wheat HKT1;4 and $\mathrm{HKT} 1 ; 5)$, decrease $\mathrm{Na}^{+}$accumulation in bread wheat leaves under saline and waterlogged conditions. J. Exp. Bot. 2011, 62, 2939-2947. [CrossRef] [PubMed] 
16. Greenway, H.; Munns, R. Mechanism of salt tolerance in nonhalophytes. Ann. Rev. Plant Physiol. 1980, 31, 149-190. [CrossRef]

17. Meteorological Office of Chile. Weather Description of Metropolitana Region. Available online: http: / / www.meteochile.cl/PortalDMC-web/index.xhtml (accessed on 10 February 2018).

18. Soltanpour, P.N.; Jones, J.B., Jr.; Workman, S.M. Optical Emission Spectrometry. In Methods of Soil Analysis. Part 2. Chemical and Microbiological Properties; Page, A., Ed.; American Society of Agronomy: Madison, WI, USA, 1982; pp. 29-65.

19. Bates, L.; Waldren, P.; Teare, I. A rapid determination of free proline for water stress studies. Plant Soil 1973, 39, 205-207. [CrossRef]

20. Yildirim, E.; Taylor, A.G.; Spittler, T.D. Ameliorative effects of biological treatments on growth of squash plants under salt stress. Sci. Hortic. 2006, 111, 1-6. [CrossRef]

21. Oliveira, M.L.; Menezes, A.C.; Aragao, M.; Fernandes de Melo, D. Salt modulation of vacuolar $\mathrm{H}^{+}$ATPase and $\mathrm{H}^{+}$-Pyrophosphatase activities in Vignaunguiculata. J. Plant Physiol. 2001, 158, 545-551. [CrossRef]

22. Munns, R.; Rawson, H. Effect of salinity on salt accumulation and reproductive development in the apical meristem of wheat and barley. Aust. J. Plant Physiol. 1999, 26, 459-464. [CrossRef]

23. Shi, H.; Quintero, F.J.; Pardo, J.M.; Zhu, J.-K. The putative plasma membrane $\mathrm{Na}^{+} / \mathrm{H}^{+}$antiporter $\mathrm{S}_{\mathrm{O}} \mathrm{S}_{1}$ controls long distance $\mathrm{Na}^{+}$transport in plants. Plant Cell 2008, 14, 465-477. [CrossRef]

24. Musyimi, D.M.; Netondo, G.W.; Ouma, G. Growth of Avocado Plants Under Saline Conditions. Int. J. Fruit Sci. 2008, 7, 67-69. [CrossRef]

25. Bernstein, N.; Meiri, A.; Zilbersaine, M. Salt-stress effects on avocado rootstock growth. I. Establishing criteria for determination of shoot growth sensitivity to the stress. Plant Soil 2001, 233, 1-11. [CrossRef]

26. Khan, M.S.; Zaidi, A.; Wani, P.A.; Oves, M. Role of plant growth promoting rhizobacteria in the remediation of metal contaminated soils. Environ. Chem. Lett. 2009, 7, 1-19. [CrossRef]

27. Wahome, P.K.; Jesch, H.H.; Grittner, I. Effect of the $\mathrm{NaCl}$ on the vegetative growth and flower quality of roses. J. Appl. Bot. 2000, 74, 38-41.

28. Ruiz, D.; Martinez, V.; Cerda, A. Demarcating specific ion $\left(\mathrm{NaCl}, \mathrm{Cl}^{-}, \mathrm{Na}^{+}\right)$and osmotic effects in the response of two citrus rootstocks to salinity. Sci. Hortic. 1999, 80, 213-224. [CrossRef]

29. Mickelbart, M.V.; Robinsona, P.W.; Witneya, G.; Arpaia, M.L. 'Hass' avocado tree growth on four rootstocks in California. II. Shoot and root growth. Sci. Hortic. 2012, 143, 205-210. [CrossRef]

30. Mansour, M. Nitrogen containing compounds and adaptation of plants to salinity stress. Biol. Plant 2000, 43, 491-500. [CrossRef]

31. Liu, J.; Xia, J.; Fang, Y.; Li, T. Effects of Salt-Drought Stress on Growth and Physiobiochemical Characteristics of Tamarix chinensis Seedlings. Sci. World J. 2014, 2014, 765840. [CrossRef] [PubMed]

32. Du Jardin, P. Plant biostimulants: Definition, concept, main categories and regulation. Sci. Hortic. 2014, 196, 3-14. [CrossRef]

33. Bernstein, N.; Meiri, A.; Zilbersaine, M. Root growth of avocado is more sensitive to salinity than shoot growth. J. Am. Soc. Hort. Sci. 2004, 2, 188-192.

34. Shahbaz, M.; Mushtaq, Z.; Andaz, F.; Masood, A. Does proline application ameliorate adverse effects of salt stress on growth, ions and photosynthetic ability of eggplant (Solanum melongena L.)? Sci. Hortic. 2013, 164, 507-511. [CrossRef]

35. Grattan, S.R.; Grieve, C.M. Salinity-mineral nutrient relations in horticultural crops. Sci. Hortic. 1999, 78, 127-157. [CrossRef]

36. Silveira, J.A.; Melo, A.R.; Viegas, R.A.; Oliveira, J.T. Salinity-induced effects on nitrogen assimilation related to growth in cowpea plants. Environ. Exp. Bot. 2001, 46, 171-179. [CrossRef]

37. Pardossi, A.; Malorgio, F.; Tognoni, F. Salt tolerance and mineral relations for celery. J. Plant Nutr. 1999, 22, 151-161. [CrossRef] 
38. Rubinigg, M.; Wenisch, J.; Elzenga, J.; Stulen, I. NaCl salinity affects lateral root development in Plantago maritima. Funct. Plant Biol. 2004, 8, 775-780. [CrossRef]

39. Kamran, M.; Shahbaz, M.; Ashraf, N. Alleviation of drought-induced adverse effects in spring wheat (Triticum aestivum L.) using proline as a pre-sowing seed treatment. Pak. J. Bot. 2009, 41, 621-632.

(C) 2018 by the authors. Licensee MDPI, Basel, Switzerland. This article is an open access article distributed under the terms and conditions of the Creative Commons Attribution (CC BY) license (http:/ / creativecommons.org/licenses/by/4.0/). 